\title{
Economic Contribution of Non-Timber Forest Products in Rural Livelihood of Dolakha, Nepal
}

\author{
Sabina Maharjan \\ Singhania University, School of Science, Rajasthan, INDIA \\ Megh R. Dangal \\ Kathmandu University, School of Arts, NEPAL
}

Received: 31 May 2020 - Accepted: 19 July 2020 - Published Online: 17 September 2020

\begin{abstract}
Non-timber forest products (NTFP) are reported to have significant contribution in household economy supporting their subsistence. The study focuses on the share of NTFPs income in household income along with other sources. Forty-six households were sampled to carry out the targeted study. To analyze the contribution of NTFPs in household income, structured household questionnaires were designed for quantitative data and focus group discussion and key informant interview was conducted to obtain in-depth information guided by a checklist of questions. The major NTFPs found in the study area are Asparagus, Terminalia chebula, Phyllanthus, Terminalia bellerica, Edgeworthia (Argeli), Daphne (Lokta), Swertia (Chiraito), Taxus, Cinnamomum, mushrooms, firewood, and bamboo. Ninety six percent of community is involved in NTFPs collection either for subsistence or income. The study reveals that the agriculture share the highest income of $45.65 \%$ and NTFPs share $26.08 \%$ to average monthly income of household. District Forest Office and middlemen made CFUGs collect the NTFPs according to the prevailing market demand for which the collectors are paid certain amount. However, these days there is less demand of NTFPs collection as they are not getting the market for the collected NTFPs and do not have idea regarding the market demands to cultivate those products.
\end{abstract}

Keywords: Non-timber forest products, economic contribution, livelihood, biodiversity conservation, Nepal.

\section{Introduction}

Globally, forest resources have significant economic contribution to rural livelihood, especially to forest dwellers. The report estimates about 1.6 billion rural people dependency on forest resources to certain extent. One billion extreme poor depend partly on forest products and 300-350 million people are highly dependent on those resources for subsistence as well as income (Chao, 2012). Collection and sale of NTFPs are a significant livelihood diversification for the marginalized family supporting remarkably in their household incomes (Melaku et al., 2014; RosTonen, 2000). Their dependency on these products largely increases during the period of hardships as they act as safety net for them (Anderson \& Wunder, 2003).

Dependency to forest resources and their contribution to incomes vary globally as their utilization depends on their socio-economic status. People with poor economy are found to be

(C) Authors. Terms and conditions of Creative Commons Attribution 4.0 International (CC BY 4.0) apply. Correspondence: Megh Raj Dangal, Associate Professor, Kathmandu University, School of Arts, Kathmandu, NEPAL. E-mail: megh@ku.edu.np. 
involved more in the utilization of forest resources. African's livelihood is largely affected by the forest resources. The African continent's people live on less than 1.25 US dollar a day and their subsistence is retained by forest resources that provide them some economic activities (Anderson et al., 2006). Forest resources have been the sources for medicines, nutrition and other values as well along with income generation. More recently, there has been a growing interest in the economic potential of NTFPs as their prospects in poverty reduction raising their livelihood status and sustainable development have been recognized.

Millions of livelihoods are dependent on Non-timber forest products (NTFPs) at global level to overcome their basic needs. Over 50 million Indians are found to be dependent on NTFPs for their subsistence and cash income (Shaanker et al., 2004). Mulenga et al. (2011) reported the contribution of NTFPs to rural household income and food security in Zambia that has great influence over the national economy. Non-timber forest products have been contributing to forest dwellers get their poverty better of through income generation as well as supportive in household consumptions (Chikamai \& Kagombe, 2002). People across the world have dependence over NTFPs in different forms as nutrition, forage, energy, medicine, fibres, resins oils (FAO, 1991), to sustain their livelihood subsistence or to generate income for their living.

Contribution of NTFPs to rural people and forest dwellers in context of Nepal is also remarkably noticeable. Certain reports have highlighted their economic contribution on rural livelihood. Still there is paucity in information and scientific records of economic contribution of forest resources in Nepal (Subedi, 2006). However, some micro-level studies have been carried out on economic contribution of overall forest products. There is no separate record for nontimber forest products' contribution. The forestry sector is considered to highly supportive in contributing to the national GDP through trade. Still the enumeration lacks many aspects of economic valuation of products and services that are generated from the forest products.

Nepal being rich in biodiversity, it shelters more than 700 medicinal plants among which 100 are actively traded. To promote their value, Nepal Government also has prioritized 30 species and has permitted 12 species for commercial cultivation and market promotion (AEC/FNCCI, 2004). It is estimated that about 10,000 to 15,000 tons of plant products of more than 100 species are exported to India annually (Edwards, 1996). There is still need of reporting the data regarding economic value and contribution of NTFPs as the data available fails to explain the definite value of non-timber forest products.

This study explores the major sources of livelihood and importance of NTFPs in their livelihood. The major objective of the study is to investigate the economic contribution of NTFPs in household income of rural people of the study area. Economic contribution is investigated through (i) share of NTFPs income in the total household income and expenditure, (ii) factors determining the engagement of household in NTFPs collection, and (iii) socio-economic determinants for the dependence on NTFPs income.

\section{Literature review}

Development of rural economy depends on successful trade of natural resources as remote areas hold excess space for forests. Trade of these resources generates employment to rural people that help to combat them struggle for daily needs. Forest-based activities in developing countries like Nigeria, especially in NTFPs abundant areas, facilitate people through income providing an equivalent of 17 million full-time formal job and 30 million informal jobs (Duong, 2008). Income of 80\% (Jimoh, Amusha \& Azeez, 2013) is generated from the sales of NTFPs.

Contribution of NTFPs in rural household economy is recognized globally. The significance of NTFPs in household income is sometimes equal to more than the school teachers' minimum wages in Central and West Africa (Shackleton, Shackleton, Buiten \& Bird, 2007). 
Approximate USD 90 billion per annum economy (Pimentel et al., 1997; Mahapatra \& Tewari, 2005) is estimated for NTFPs in global context, of which one-third is consumed by local economy.

Economic status of people living in remote and mountainous regions is very critical. One of the easy means to raise their economic status is making them involve in trade of NTFP species. Collection and selling of NTFPs can generate employment for them, hence contributing their livelihood diversification. Poor people can make money through the sale of economically valuable species.

As reported in Nepal by Olsen (1998), 470,000 households are involved in NTFPs collection to make money. The rate of people's engagement has increased so high these days. Nepal has a long history of trade of these valuable species to India as well as to other International markets. About 10,000 to 15,000 tons of plant products are supported to be traded to India and other international markets (Bhattarai, 1997). Among the products, 20 NTFPs species (Bhattarai \& Olsen, 2000) are highly demanded economically valuable products that are exported.

Non-timber forest products with high economic value could be one of the major means to raise the economy level of the country as well. As remote areas form the major part of the country, their upliftment is prime necessity. The rural development can be better enhanced by the proper utilization of natural resources. Nepal, being rich in biodiversity, has enough potentiality in rural as well as national development through the proper utilization of these resources. Revenue from forest resources is reported to be in that level which supports raising economic status of rural people and of a whole nation.

Melaku et al. (2014) through their study in Southwestern Ethiopia reported that NTFPs contributed $47 \%$ to annual household income. In Western Uganda, Jagger (2012) estimated the rural Ugandans derive $26 \%$ of total household income from forest resources \& other ecosystems. High dependence on NTFPs in humid tropics of Northeast India is revealed to contribute 19-32\% of total household income (Saha \& Sundriyal, 2011). Heubach (2011) found that total household income is supported by $39 \%$ of NTFPs income in northern Benin. The community of China State of Myanmar is advantaged about 50\% to 55\% through forest income (PyiSoe et al., 2014).

The extraction of Non-timber forest products is largely increased with the recognition of its importance in all aspects of human life as well as ecologically. Besides supporting livelihood and income generation to rural communities, they have created their value in international markets as well. The unmanageable collection and use of the resources cause depletion and degradation of forest ecosystem. The increase demand for livelihood has been questionable on compatibility of NTFPs extraction and biodiversity conservation. Forest conservation efforts are being challenged, yet their contribution in subsistence and income is efficiently recognized.

\section{Research methods}

\subsection{Study site}

The field study conducted for the purpose of this research took place in community forest of Magha-Deurali at Dolakha district, Nepal. People of community forest are utilizing forest products for their livelihood for cash and no-cash income. The study conducted in Dolakha district enabled us to study awareness of user group towards the importance of non-timber forest products and mechanism of their utilization in remote areas. 


\subsection{Sampling}

To identify the contribution of NTFPs in livelihood of community, 46 households of Magha-Deurali community forest were selected randomly. The field survey was conducted in February 2020. Household survey was carried out with the respondents on random selection and for focus group discussion, the respondents included user groups and members of community forest. Key informant interview was conducted with key personnel selected purposively.

\subsection{Research design and tools}

The study followed a quantitative research design complemented by qualitative design. Structured questionnaires were constructed to carry out household survey with randomly selected households. The questionnaires for household survey were administered to household head, and in absence of them, other family members having idea of NTFPs were interviewed. The questionnaires and guidelines for focus group and KII were prepared prior to the survey, but were extended when required.

\subsection{Data analysis and interpretation}

Both descriptive and inferential statistics were used for data analysis. Descriptive statistics including the frequency, percentages and bar chart were used to summarize the contribution of NTFPs to households' livelihoods and partly the relative contribution of NTFPs to household income. ANOVA and bivariate correlation were used to determine the factors that influence the collection and utilization of NTFPs by households. Data collected during FGD and KII were transcribed and coded. The information elicited from FGD and KII were used to triangulate the household survey tools and for interpretation of results.

\section{Findings and analysis}

\subsection{Demographic and socio-economic profile}

During the household survey, different socio-economic information was collected to determine the dependency of respondents on NTFPs income. The average family size in the study area was 4 with a minimum of 1 and maximum of 10 household members. The average education level is 3.8, among them most of the respondents were accessed to vocational education (Figure 2). Average age of the respondents is 48.48 years with a minimum of 20 years and maximum of 70 years. All households possess agricultural land to some extent. The average agricultural land size is 9.5 ropani ( 1 ropani $=508.72 \mathrm{~m}^{2}$ ). $76 \%$ of respondent's primary occupation is agriculture and $20 \%$ respondents are involved in non-farm activities (Figure 3). The socio-economic attributes of the study area are presented in Table 1.

Table 1. Descriptive statistics of household characteristics

\begin{tabular}{|c|c|c|c|c|c|c|}
\hline $\begin{array}{l}\text { Household } \\
\text { Characteristics }\end{array}$ & Minimum & Maximum & Median & Mean & $\begin{array}{l}\text { Standard } \\
\text { Deviation (SD) }\end{array}$ & $\begin{array}{l}\text { Standard } \\
\text { Error }\end{array}$ \\
\hline Family Size & 1 & 10 & 4.00 & 4.326 & 1.989465 & 0.293330612 \\
\hline Age & 20 & 70 & 49.00 & 48.48 & 11.30534 & 1.666880894 \\
\hline Education & $\begin{array}{l}\text { o } \\
\text { (Intermediate } \\
\text { and Above) }\end{array}$ & 6 (None) & 6.00 & 3.891 & 2.311596 & \\
\hline Land Owned & $\mathrm{O}$ & 25 & 7.00 & 9.522 & 7.582844 & 1.118029292 \\
\hline $\begin{array}{l}\text { Household } \\
\text { Income (Rs) }\end{array}$ & o & 35,000 & 5,416 & 7,749 & 8428.664 & 1242.738773 \\
\hline
\end{tabular}




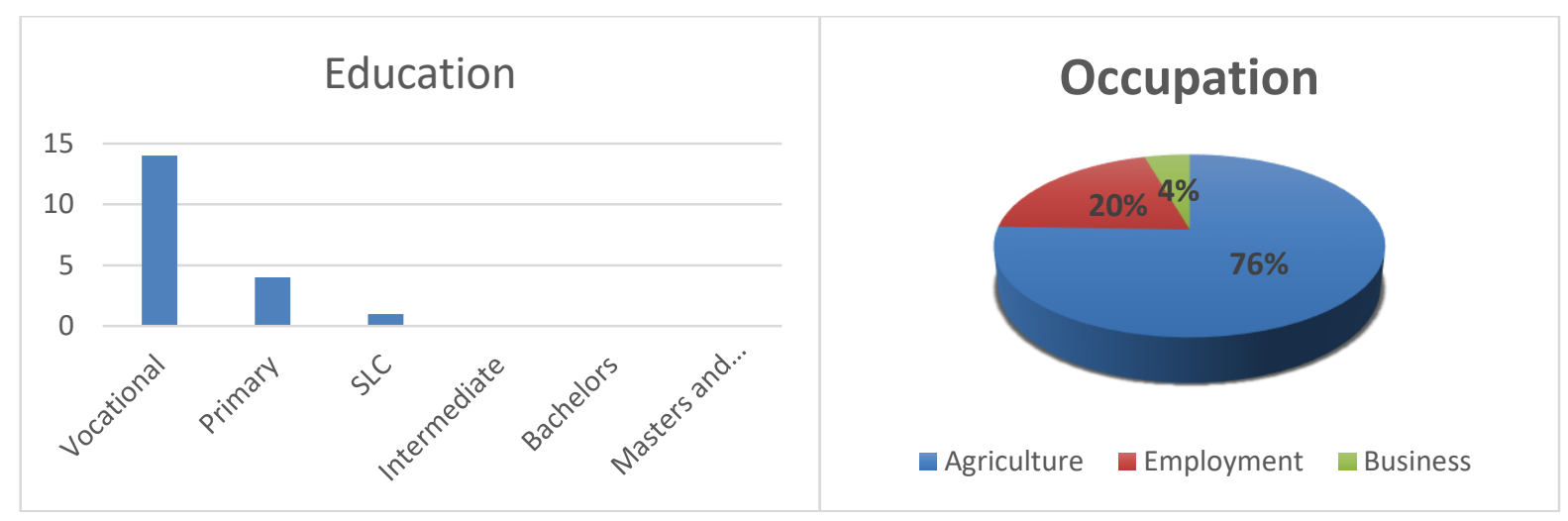

Figure 2. Educational status of respondents

Figure 3. Occupational status of respondents

4.2 Available NTFPs and involvement of people in collection:

The study revealed that $96 \%$ people of Magha-Deurali were involved in the collection of non-timber forest products. The main purpose of the collection was for household consumption (43\%), 30\% people collect them for treatment and 27\% people's motive was for trade (Figure 4). Less percentage of people involvement in trade can be accounted to the lack of market knowledge and trader's information. For example, a participant (Sabita Thami, aged 40 years) involved in NTFPs collection said:

"We don't know regarding market to sell the collected products. Agents asked us to collect the products and we do the same and handover to them. We are not involved in marketing ourselves as we do not know the demand of the market."

Most of the people in the study site have normal education background and collectors are of old-aged group because of which they do not have much idea about market and its approach technique. The complexity in market chain could be the hurdle to market the collected products directly by the collectors. People are comfortable using the products for their subsistence and medicinal purpose rather than for trade. The major NTFPs contributing in subsistence and cash income are listed in Table 2. Majority of household is engaged in collection of medicinal plants and least in bamboo collection. Medicinal plants are utilized for own treatment purpose and less in trade.

Table 2. Major NTFPs available and involvement of respondents in collection

\begin{tabular}{lcc}
\hline \multicolumn{1}{c}{ NTFPs } & No. of engaged households & $\begin{array}{c}\text { Proportion of Households } \\
\text { engaged in \% }\end{array}$ \\
\hline Wild Fruits & 21 & $46 \%$ \\
Mushroom & 32 & $70 \%$ \\
Bamboo Products & 19 & $42 \%$ \\
Medicinal and Aromatic Plants & 45 & $97 \%$ \\
\hline
\end{tabular}


S. Maharjan \& M. R. Dangal - Economic Contribution of Non-Timber Forest Products in...

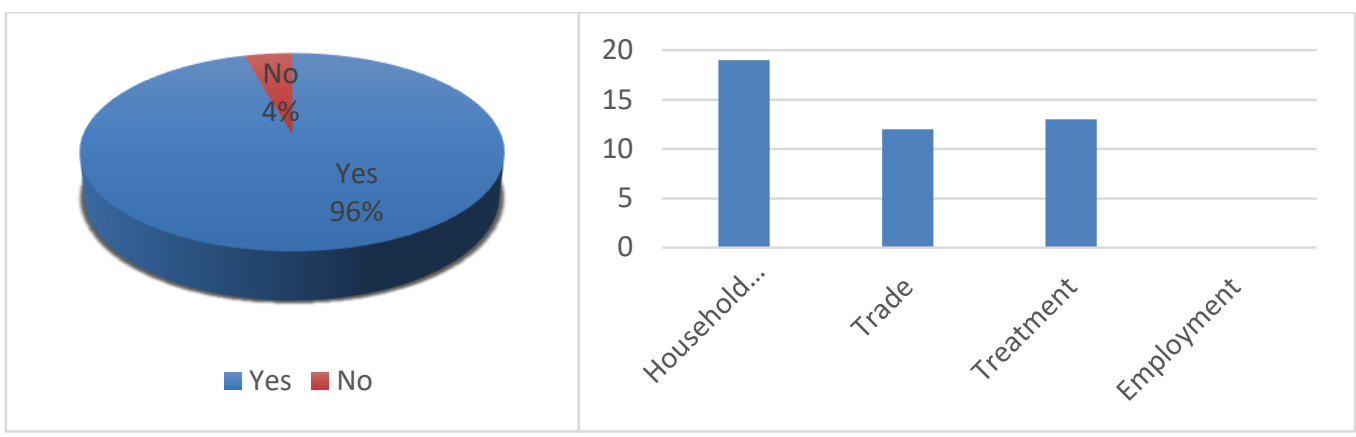

Figure 3. Involvement of respondents in collection Figure 4. Purpose of collection

The access to agricultural land and livestock is inversely related to NTFPs collection. As they need to contribute most of their time in agriculture, they could provide very less time for NTFPs collection however, they could manage to collect fodder for their cattle and firewood for their household consumption. For example, a respondent (Tej Kumari Shrestha, 42 years) said:

"We do not have much time to get involved in collection as we need to look after agriculture and livestock we are rearing. We collect fodder for them and only firewood from the forest whenever we need."

\section{Income generated from NTFPs and other sources}

The major livelihood strategies in the study are farming, non-farm activities and NTFPs collection. As shown in Table 3, income from agriculture was the major and the highest income source ( $45.65 \%$ share to the household income). Non-farm income is the second largest share with $28.26 \%$ and NTFPs income shares 26.08\%. Agriculture being the main occupation shares the maximum income to household. The main crops grown are maize, paddy, spinach and in large quantity potatoes are produced. People mostly sold potatoes whereas other crops are limited for their own consumption only. For example, a woman (Anita Tamang, 31 years) whose main occupation is agriculture said:

"We go to forest for fodder for our livestock twice in a week. Our main occupation is agriculture and mainly potatoes are grown which we sell in the market. The income we receive from its sale ranging from Rs. 50,00O-1, 50,00O which we utilize for our household needs."

Even the income from NTFPs shares less percentage; it is supportive for hard times and insufficient agricultural production. The result corroborated with the study carried out by Maleku et al. (2014) who reported agriculture as major sources of income sharing 50\% to household income. Saha and Sundriyal (2011) also revealed the dependency of tribal communities of northeast India on NTFPs that contributed 19-32\% to total household income.

Table 3. Average monthly income of household through different sources

\begin{tabular}{lrrrrr}
\hline Income Source & \multicolumn{1}{c}{$\begin{array}{l}\text { Total } \\
\text { Income }\end{array}$} & $\begin{array}{l}\text { Average Income } \\
\text { per Month }\end{array}$ & $\begin{array}{l}\text { Standard } \\
\text { Deviation }\end{array}$ & \multicolumn{1}{c}{$\begin{array}{l}\text { Standard } \\
\text { Error }\end{array}$} & \multicolumn{1}{c}{$\begin{array}{l}\text { Income } \\
\text { Share }\end{array}$} \\
\hline Farm Income & $1,94,200$ & 9247.619048 & 10364.00594 & 2261.61151 & $45.65 \%$ \\
Non-Farm Income & 139833 & 10756.38462 & 6109.598726 & 1694.497806 & $28.26 \%$ \\
NTFPs Income & 22400 & 1866.666667 & 1374.001015 & 396.6399278 & $26.08 \%$ \\
Total Income & $\mathbf{1 , 6 2 , 2 3 3}$ & $\mathbf{2 1 , 8 7 0 . 6 7}$ & & & $\mathbf{1 0 0 \%}$ \\
\hline
\end{tabular}

People also admitted that they are getting engaged more in labor activities after the time of earthquake as the construction activities as they are not getting market for NTFPs. As such, a respondent (Ganesh Pakwal, 35 years old) said: 
"People were involved in the collection of Chiraito including me and even cultivated the species in our own land. From it, we used to earn up to Rs. 2000 per day. But since few years we are not getting market for this product and people are diverting into labor activities and construction work is also being encouraged extensively after 2072 B.S. earthquake."

The diversion to labor work can be inferred to payment they receive higher than NTFPs income. Insufficient market knowledge for trade and less production of NTFPs also have led them to get engaged in other wage activities and depends non-farm income.

\section{Share of NTFPs income on household expenditure}

Most of CFUG's education is very basic and have minimal knowledge on NTFPs trade. Involvement of respondents in NTFPs collection is maximum, but depends on third party or agents to sell the products. Direct link to the market is very difficult for them because of complexity in trade formalities. Middle agents provide less benefit return to the collectors which discourage them for collection. But some are actively involved in the collection along with trade and have earned good amount sustaining their families' necessities.

Those who receive fewer amounts, they could spend very nominal amount in food and was not so enough for other activities. Those getting larger amount have good support on expenses on food (39.13\%), education (15.21\%), health (4.35\%) and could also do saving of 8.7\% (Table 4). For example, a member of community forest user group (Bhim Thami, 40 years old) said:

"My main occupation is NTFPs collection and its trade. I have been engaged in collection since long and make some of the user groups engage too. I contact directly to the vendors in the market and sometime through agents. The earnings I have been able to spend in the education of my children and other basic activities as well are being supported."

Table 4. Share of NTFPs income on different categories' expenses

\begin{tabular}{lrlrlr}
\hline Category & Frequency & $\begin{array}{l}\text { Total } \\
\text { Expenditure }\end{array}$ & Percentage & $\begin{array}{l}\text { Actual } \\
\text { Expense }\end{array}$ & Average \\
\hline Food & 18 & $1,91,033$ & $39.13 \%$ & $1,20,103$ & 6672.39 \\
Education & 7 & 82,200 & $15.21 \%$ & 35,554 & 5079.143 \\
Health & 2 & 15,000 & $4.35 \%$ & 11,500 & 5750 \\
Saving & 4 & 19,000 & $8.70 \%$ & 10850 & 2712.5 \\
None & 15 & 0 & $32.60 \%$ & & \\
\hline
\end{tabular}

Those who were involved less in the collection and have very nominal knowledge about NTFPs market and their price; they could obtain very less amount and could spent earnings from NTFPs on few food items only. For example, Krishna Bahadur Shrestha (33 years old) said:

"I am involved in NTFPs collection and handover to middlemen. Middlemen do payment to us and we receive the amount without any argue as we do not have idea about the actual price so we accept whatever is given. I can spend very small amount to purchase food items like oil, salt, sugar, etc. only. The earning is not enough to spend on other household activities."

The respondents who receive less amount from NTFPs and lack agricultural land tend more to be involved in off-farm activities. They relatively receive more amounts from off-farm activities than NTFPs collection. 


\section{NTFPs Dependency}

One-way analysis of variance (ANOVA) and bivariate relation were carried out to survey NTFPs income against household socio-economic variables and NTFPs income against other income sources. One-way analysis of variance of the survey data shows (Table 5) shows that households carry no significant difference in NTFP income depending on different education level of participants. The analysis suggests that households with primary education yield more income than those having no education. As obvious, male headed households fetch more income from NTFPs than female headed households. Female have to look after their home and their children because of which they can spend less time in collection than males. As occupation is considered, agriculture is the main occupation of the study site; participants with major agriculture income source make less income from NTFPs than those involved in other employments. The respondents engaged in off-farm activities may partly involve themselves in NTFPs collection as the employment source can be unsecured.

Table 5. Effects of socio-economic variables on NTFPs income

\begin{tabular}{lcccc}
\hline $\begin{array}{l}\text { Explanatory } \\
\text { Variables }\end{array}$ & $\mathrm{N}$ & $\begin{array}{l}\text { Mean NTFP } \\
\text { income/Month }\end{array}$ & F-value & p-value \\
\hline Education & & 7371.43 & & \\
Vocational & 14 & 13250.00 & & \\
Primary & 4 & 3000.00 & & \\
Secondary & 3 & 1000.00 & .821 & .520 \\
SLC & 1 & 7926.38 & & \\
None & 24 & & &
\end{tabular}

\section{Gender}

Female

Male

\section{Occupation}

Agriculture

Employment
25

21

36

7
7221.32

8376.19

.211

.649

Bivariate correlation among the NTFP income and socio-economic variables is presented in Table 6. Among the explanatory variables; agricultural land $(\mathrm{P}<0.05)$ is statistically significant and negatively correlated with NTFPs income. Agricultural land is the important factor that has major impact on livelihood which likely to reduce the dependency of local community on NTFPs. This result supports other findings as well. Babulo et al. (2008) found that households with large plots of land were less likely to engage in natural resources extraction. In our study, land owned by the communities also does not signify the dependence of the communities over the NTFPs. Even the households own land, they are not capable to utilize it for their subsistence owing to less production or the destruction of crops by the wild animals. Age is negatively correlated with the NTFPs income, as the age of the respondents is more; they are less likely to engage in NTFPs collection. Numbers of household members $(\mathrm{P}<0.05)$ and positively correlated. More the family members, more they can harvest NTFPs.

Furthermore, Education of the respondents is negatively correlated to NTFPs income. The finding is reverse to other studies. Melaku et al. (2014), PyiSoe et al. (2014) revealed education positively related to NTFPs income. In our survey, education is negatively correlated to NTFPs income as educated people have alternative options of employment and are less likely to engage in NTFPs collection. 
Farm income in the study encompasses agricultural crops income. The households having significant income through farming are less dependent on environmental income; however, there is no significant conclusion. Non-farm income is negatively correlated with NTFPs income and is statistically significant $(\mathrm{p} \leq 0.1)$. NTFPs dependency was reduced if the household have better income from non-farm employment.

Table 6. Bivariate relationship between different socio-economic factors of monthly household income from NTFP's

\begin{tabular}{lcc}
\hline Variables & $\begin{array}{l}\text { Bivariate relationship with NTFPs } \\
\text { Income }\end{array}$ \\
\hline Age & & -.105 \\
Gender & .069 \\
Education & -.006 \\
HH Size & .044 \\
Farm Income & .991 \\
Non-farm Income & -.189 \\
Land Owned & .083 \\
\hline
\end{tabular}

Significance level<0.1, 0.05, 0.001

\section{Conclusion}

Farm activities are found to be major source of income to sustain the livelihood of study area followed by non-farm income. The households of the study area have been utilizing available NTFPs in the forest both in terms of subsistence and income. The study reported that people with less non-farm activities are involved more in utilization of non-timber forest products. The NTFPs like Argeli, Lokta, chiraito are used for commercial purpose whereas bamboo and firewood are used for household purpose and Pakhanved, Satuwa are used for medicinal purpose. People are employed in the processing of Argeli which is exported in Japan for making currency and Lokta through which paper is produced that is distributed across the developed countries. The communities with better access to farm and non-farm activities are found less dependent on NTFPs income.

Utilization of non-timber forest products by forest dwelling people can be boon to combat with their economic crisis and food insecurity. Numerous edible products are found in the wild which are consumed very less. It could be due to unawareness they have regarding the properties they carry. Along with it, they are unable to get in to the market requirements as they do not have access as well as knowledge to market approach. Owing to lack of capacity, they are compel to follow their middle-agents for trade which do not benefit them to the level which can improve their economic status.

Economic status of community can be better developed in case there is proper monitoring on benefits the stakeholders involved in the process share. District forest Office should be more aware on providing market knowledge and related information as the community user groups do not have prominent knowledge regarding demanding market. In case they could have good market access information, NTFPs collection can be also their one of the main occupations and should not only rely on agricultural products for their food. Awareness on economic value of NTFPs should be created on rural people so that they can utilize those resources at optimum level being conscious on their conservation. 


\section{Acknowledgements}

This research did not receive any specific grant from funding agencies in the public commercial, or not-for-profit sectors.

The authors declare no competing interests.

\section{References}

AEC/FNCCI (2004). Trade pattern of non-timber forest products (NTFPs) in Jumla, Surkhet and Nepalgunj: Appropriate policy measures for business and trade enhancement. Federation of Nepalese Chambers of Commerce and Industry, Agro Enterprise Center, Nepal.

Anderson, J., Benjamin, C., Campbell, B., \& Tiveau, D. (2006). Forests, poverty and equity in Africa: New perspectives on policy and practice. International Forestry Review, 8, 44-53.

Angelsen, A., \& Wunder, S. (2003). Exploring the forest - Poverty link: Key concepts, issues and research implications. International Forestry Research (CIFOR), Bogor, Indonesia.

Babulo, B. Muys, B., Nega, F., Tollens, E., Nyssen, J., Deckers, J., Mathijs, E., (2008). Household livelihood strategies and forest dependence in the highlands of Tigray, Northern Ethiopia. Agricultural Systems, 98 (2008), 147-155.

Bhattarai, N. (1997). Biodiversity-people interface in Nepal. In: Medicinal plants for forest conservation and health care. Non-wood forest product series, 11, 78-86.

Bhattarai, N., \& Olsen, C. (2000). Towards a generic framework for investigating national importance of medicinal plant trade. In S. M. Amatya (Ed.), Proceedings of the third regional workshop on community based NTFP management, South and East Asian countries NTFPS network (SEAN) (pp. 336-346). Institute of Foresty, Pokhara, Nepal.

Chao, S. (2012). Forest peoples: Numbers across the world. Forest People Program, United Kingdom.

Chikamai, B. N., \& Kagombe, J. (2002). Country report for Kenya. In Review and synthesis on the state of knowledge of Boswellia spp. and commercialization of Frankincense in the drylands of Eastern Africa, KEFRI, Nairobi, Kenya.

Duong, N. (2008). The role of non-timber forest products in livelihood strategies and household ecomomics in a remote upland village in the upper ca river basin, Nghe the Phoung. Journal of Science and Development, 1, 88-98.

Edwards, D. M. (1996). Non-timber forest products from Nepal: Aspect of the trade in medicinal and aromatic plants. FORESC Monograph 1/96, Forest Research and Survey Center, Ministry of Forests and Soil Conservation, Kathmandu, Nepal.

FAO (1991). Forest industry: Crucial for overall socio-economic development. Unsylva, 42, 16-24.

Heubach, K. et al. (2011). The economic importance of non-timber forest products (NTFPs) for livelihood maintenance of rural West African communities: A case study from northern Benin. Ecological Economics, 70, 1991-2001.

Jagger, P. (2012). Environmental income, rural livelihoods, and income inequality in western Uganda. Forests, Trees and Livelihoods. https://doi.org/10.1080/14728028.2012.698846

Jimoh, S., Amusha, T., \& Azeez, I. (2013). Population distributions and threats to sustainable management of selected non-timber forest products in tropical lowland rainforest of Southwestern Nigeria. Journal of Forest Resources, 24(1), 75-82.

Mahapatra, A., \& Tewari, D. (2005). Importance of non-timber forest products in the economic valuation of dry deciduous forests of India. Forest Policy Economy, 7(3), 455-467. 
Melaku, E., Ewnetu, Z., \& Teketay, D. (2014). Non-timber forest products and household incomes in Bonga forest area, Southwestern Ethiopia. Journal of Forestry Research, 25(1), 215-223. https://doi.org/10.1007/s11676-014-0447-0

Mulenga, P. B, Richardson, R. B, Mapemba, L., \& Tembo, G. (2011). Contribution of non- timber forest products to rural income in Zambia. Policy synthesis food security research project Zambia. Ministry of Agriculture and Cooperatives, agricultural Consultative Forum, Lusaka, Zambia, http://www.aec.msu/fs2/zambia/Index.htm.

Olsen, C. S. (1998). The trade in medicinal and aromatic plants from central Nepal to northern India. Economic Botany, 52(3), 279-292.

Pimentel, D., McNair, M., Buck, L., Pimentel, M., \& Kamil, J. (1997). The value of forests to world food security. Journal of Human Ecology, 25(1), 91-120.

PyiSoe, A., Yahia, O. A., Jurgen, P., \& Rony, P. (2014). Distribution of forest income among rural households: A case study from Natma Taung national park, Myanmar. Forests, Trees and Livelihoods. https://doi.org/10.1080/14728028.2014.976597

Ros-Tonen, M. A. F. (2000). The role of non-timber forest products in tropical forest management. HolzalsRoh-und Werkstoff, 58, 196-201.

Saha, D., \& Sundriyal, R. C. (2011). Utilization of non-timber forest products in humid tropics: Implications for management and livelihood. Forest Policy and Economics, 14, 28-40.

Shackleton, C., Shackleton, S., Buiten, E., \& Bird, N. (2007). The importance of dry woodlands and forests in rural livelihoods and povery alleviation in South Africa. Forest Policy Economy, 9(5), 558577.

Shaanker, R. U., Ganeshaiah, K. N., Krishnan, S., Ramya, R., Meera, C., Aravind, N. A. et al. (2004). Livelihood gains and ecological costs of non-timber forest product dependence: assessing the roles of dependence, ecological knowledge and market structure in three contrasting human and ecological settings in south India. Environmental Conservation, 31, 242-253.

Subedi, B. P. (2006). Linking plant-based enterprises and local communities to biodiversity conservation in Nepal Himalaya. New Delhi: Adroit Publishers. 
S. Maharjan \& M. R. Dangal - Economic Contribution of Non-Timber Forest Products in...

C O A $\mathrm{s}$ 